\title{
Self-Categorization and Social Identification: Making Sense of Us and Them ${ }^{1}$
}

\author{
Nils Karl Reimer, Katharina Schmid, Miles Hewstone, \& \\ Ananthi Al Ramiah
}

Social identity processes are central to social psychological theory and research. Social identity plays an important role in many individual and social phenomena, including health and well-being (e.g., C. Haslam, Jetten, Cruwys, Dingle \& Haslam, 2018), educational achievement (e.g., Steele, Spencer \& Aronson, 2002), and collective action and social change (e.g., van Zomeren, Postmes \& Spears, 2008).

In this chapter, we provide an overview of social psychological theories on social identity, including social identity theory (Tajfel, 1978; Tajfel \& Turner, 1979) and self-categorization theory (Turner, Hogg, Oakes, Reicher \& Wetherell, 1987). Prior to Tajfel's and Turner's seminal writings, two types of theory dominated explanations of intergroup relations and intergroup conflict. First, so-called 'prejudice' accounts proposed that intergroup conflict results from individual-level variation in a prejudiced personality (Son Hing \& Zanna, 2010). Second, realistic group conflict theory (Campbell, 1965; Sherif, 1966) contended that negative intergroup relations stem from conflicting group goals and competition over resources or power (see Jackson, 1993, for a review). Compared to these explanations, social identity theory and self-categorization theory offered a unique and refined account of intergroup relations that remains important to this day. This chapter is dedicated to these interrelated approaches for understanding intergroup relations. Rather than present these theories chronologically-or focus on differences and similarities across the two theories-we take a more encompassing approach to what is often called the 'social identity perspective' (Abrams \& Hogg, 2010). Beyond Tajfel's and Turner's seminal writings, we focus on more recent efforts to define social identification, and discuss how multiple categorization offer insights into the dynamics underlying

${ }^{1}$ Cite as: Reimer, N. K., Schmid, K., Hewstone, M., \& Al Ramiah, A. (2020). Self-categorization and social identification: Making sense of us and them. In D. Chadee (Ed.), Theories in social psychology (2nd ed.). Wiley-Blackwell. 
intergroup relations.

This chapter is organised into five sections. The first three sections define social categorization, self-categorization and social identification, and the latter two sections examine how these processes are involved in, and help explain, intergroup relations. Section 1 introduces social categorization as a fundamental process that underlies self-categorization and social identification. Section 2 defines self-categorization as social categorization applied to oneself, and introduces selfcategorization theory as a detailed account of when, how, and why we describe ourselves in terms of social categories. Section 3 defines social identification as a multidimensional process by which we attach value and meaning to our selfcategorizations. Section 4 introduces social identity theory as a detailed account of how social identification relates to intergroup relations, focusing on findings from the minimal group paradigm. Section 5 reviews recent advances in understanding how multiple categorization shapes intergroup relations, discussing how more complex social identities across multiple categories can improve intergroup relations. We end by drawing some general conclusions, and by discussing implications of the social identity perspective for how we understand intergroup relations.

\section{From Social Categorization to Self-Categorization}

As humans, we readily categorize ourselves and others into social groups. That is, we spontaneously divide people according to ascribed categories (e.g., ethnicity or gender), achieved states (e.g., occupation or political affiliation), and other relevant distinctions (Deaux, 1996) - or, more generally, based on perceptions of similarity, proximity, and common fate (Campbell, 1958). This process of social categorization is often fast and automatic (Macrae \& Bodenhausen, 2000). For example, people recognise another person's race (Richeson \& Trawalter, 2005) or gender (Martin \& Macrae, 2007) within less than a second of stimulus presentation. Social categorization matters because it helps us navigate a social world marked by group distinctions and hierarchies, but also because it underlies harmful social stereotypes (Tajfel, 1969). Social categorization acquires further significance when applied to ourselves. As humans, we depend on groups for survival (Brewer, 2007), and thus have developed a fundamental need to belong to social groups (Baumeister \& Leary, 1995). This means that we are motivated to categorize ourselves into some groups, and out of others. In the next section, we introduce self-categorization theory as a perspective on how, when, and why individuals categorize themselves into certain social groups. 


\section{Self-Categorization Theory}

\section{Defining self-categorization}

Living in human societies, each of us belongs to some groups, but not to others. All of this chapter's authors, for example, are social psychologists-but only two of us are Germans. Self-categorization, however, is about more than the objective facts of group membership (e.g., having a degree in psychology, or owning a German passport). Instead, self-categorization means placing oneself in a social category, and thinking of oneself as a member of said category. Category membership and self-categorization need not coincide: A German citizen (with a German passport) might not consider herself German, but instead think of herself in terms of some other national or ethnic category. Similarly, someone might think of themselves as a member of a group, but might not be seen as such by others. Self-categorization theory (Turner et al., 1987) seeks to understand how, when, and why we come to categorize ourselves as part of certain groups, but not of others.

Turner et al. (1987) understand self-categorization as part of a person's selfconcept, that is, the set of cognitive representations a person holds about who they are. Specifically, self-categorization is the cognitive grouping of oneself and other members of a category as similar ("us"), in contrast to the members of another category ("them"). Self-categorization theory supposes that self-categorization is hierarchical. That is, it distinguishes between personal and social identity as distinct levels of self-categorization. ${ }^{2}$ Personal identity refers to one's sense of self as a unique individual, with unique traits and characteristics, while social identity refers to one's sense of self as a member of a collective group, with traits and characteristics that are shared with other members of the group (Turner, Oakes, Haslam \& McGarty, 1994). ${ }^{3}$ Turner et al. (1987) thus argue that the self can be conceived at different levels of inclusiveness (e.g., me as an individual; me as a group member; me as a human being).

At which level a person defines the self shapes how she relates to others, including members of the same and other groups. The level of self-categorization allows us to distinguish between interpersonal behaviour, such as interaction between friends, and intergroup behaviour, such as interactions between supporters of two

\footnotetext{
${ }^{2}$ Note that some have advocated the use of the term 'collective identity' in favour of 'social identity' (e.g., Simon \& Klandermans, 2001), given that all identities, whether personal or social, are socially constructed and socially meaningful (see also Ashmore, Deaux \& McLaughlin-Volpe, 2004). We agree in principle with this argument. Since the term social identity remains widely used in social psychological discourse, and to avoid confusion, we nonetheless use the term 'social identity' in this chapter.

${ }^{3}$ Turner et al. (1987) describe a superordinate level of self-categorization: one's sense of the self as a human being. This most inclusive level of self-categorization, however, is less relevant for most intra- and intergroup processes studied in social psychology.
} 
different football teams. Self-perception and social behaviour, however, should not be understood as either interpersonal or intergroup, but rather as varying along a continuum from purely interpersonal to purely intergroup properties (Tajfel, 1978; Turner, 1982). By considering different levels of self-categorization, selfcategorization theory helps us to understand self- and other-stereotyping, as well as ingroup- and outgroup-stereotyping. In both cases, the theory emphasises that individuals ascribe to themselves characteristics associated with their ingroup. In principle, self-categorization thus develops the earlier social identity perspective which we describe in detail later on in this chapter.

\section{When and why do people self-categorize?}

Self-categorization theory recognises not only that self-categorization is hierarchical, as outlined above, but also that self-categorization is situational. As discussed, individuals categorize themselves in terms of their personal identity or various social identities. This raises the question of when and why individuals categorize themselves in terms of a collective category (or not). Self-categorization theory states that whether an individual categorizes themself in terms of a collective category depends on the salience of that category in a given situation (Turner, 1999; Turner et al., 1987). Salience, in this case, is the degree to which a group membership shapes social perception and behaviour in a given situation (Oakes, 1987), and the extent to which group members perceive themselves as similar to other members of their own group, and as dissimilar to members of other groups (Turner, 1999). In other words, self-categorization depends on the extent to which a particular social category becomes psychologically activated in a given situation (Veenstra \& Haslam, 2000).

Whether a specific ingroup-outgroup distinction becomes salient depends on an interaction between its relative accessibility and fit (Oakes, 1987). A category's accessibility depends on an individual's immediate social context (situational accessibility), as well as the extent to which an individual tends to make use of a self-categorization across a range of situations (chronic accessibility). For example, a female student's gender category may become psychologically activated if she finds herself in a room filled with male students (high situational accessibility), but not in a room filled with female students (low situational accessibility). An example of chronic accessibility would be if the same student is part of a feminist campaign group which makes her much more aware of, and think more frequently about, her gender.

A category's fit depends on its comparative and normative fit in a given situation (Turner et al., 1994). Comparative fit is the extent to which, in a given social context, a person perceives greater similarity between the self and own-group members than between the self and other-group members (the so-called 'meta- 
contrast ratio'). In other words, the smaller the perceived differences between members within one's own group and the greater the perceived differences between one's own group and a comparative group are, the greater is the likelihood that a person will categorize themselves in terms of their own group. Normative fit is the extent to which these perceived differences between groups correspond to expected differences in meaning (S. A. Haslam, Oakes, Reynolds \& Turner, 1999; Oakes, Turner \& Haslam, 1991; Veenstra \& Haslam, 2000). Specifically, one’s own group (the ingroup) and the comparative group (the outgroup) need to comply with one's stereotypical beliefs about the differences between them (Oakes, 1987). For example, consider a situation in which a group of male and female students are asked to join either the university's rugby team or its dance troupe. Suppose that all men opt for the former, while all women choose the latter. In this situation, the two groups show high intragroup and low intergroup similarity (comparative fit), and also conform to the expected norm (normative fit).

Psychological activation of social categories sets in motion a process of depersonalization by which individuals may come to perceive themselves as interchangeable representatives of their group (Turner et al., 1994). As a result, individuals cognitively align themselves with the ingroup prototype (self-stereotyping), shift from personal to group-based perceptions and behaviours, and begin to integrate the group into their self-concept (Smith \& Henry, 1996). This process explains how individuals come to think and act in terms of their group identity (see, for example, S. A. Haslam et al., 1999; S. A. Haslam, Turner, Oakes, McGarty \& Reynolds, 1998, even to the exclusion of their personal identity. Thus far, we have described how, when, and why individuals categorize themselves in terms of social categories. Self-categorization is, however, only one part of social identification. Social psychological research emphasises that people often derive meaning from their self-categorizations and attach emotional significance to it. In the next section, we define social identification as a multi-dimensional process that goes beyond mere self-categorization.

\section{From Self-Categorization to Social Identification}

\section{Defining social identification}

Social identification varies from individual to individual, and from situation to situation, reflecting the extent to which a group membership is incorporated into an individual's self-concept (e,g, Branscombe \& Wann, 1994; Waddell \& Cairns, 1986). In its simplest definition, social identification denotes that an individual perceives their group and their membership thereof as meaningful, desired, and important. Social identification is a broad term that summarises a complex set of processes 
underlying group membership (Deaux, 1996). Definitions tend to recognise that social identification is a multidimensional phenomenon. Henri Tajfel, for example, defined social identity as "that part of an individual's self-concept which derives from his knowledge of his membership in a social group (or groups) together with the value and emotional significance attached to that group membership" (1981, p. 255). Tajfel's writings, including this definition, form the foundation of social identity theory (Tajfel, 1978; Tajfel \& Turner, 1979, 1986).

This early definition implies that social identification consists of three components (see also Ellemers, Kortekaas \& Ouwerkerk, 1999; Jackson, 2002; Phinney, 1990): a cognitive component (self-categorization), an evaluative component (the degree to which a person evaluates a group in positive or negative terms), and an affective component (the extent to which a person feels emotionally tied to a group). More recent definitions of social identification include additional dimensions (see, for example, Cameron, 2004; Deaux, 1996; Jackson \& Smith, 1999; Sellers, Rowley, Chavous, Shelton \& Smith, 1997). Leach et al. (2008) empirically confirmed a hierarchical model of social identification that contains two dimensions, self-definition (subdivided into individual self-stereotyping and ingroup homogeneity) and selfinvestment (subdivided into solidarity, satisfaction and centrality). Ashmore et al. (2004) formulated the, to date, most comprehensive framework for conceptualising social identification, which we summarise in the next section.

\section{Dimensions of social identification}

Ashmore et al. (2004) carried out an extensive review of the existing literature on social identification, and concluded that social identification consists of seven theoretically distinguishable components: (1) self-categorization, (2) evaluation, (3) importance, (4) attachment and interdependence, (5) social embeddedness, (6) behavioural involvement, and (7) content and meaning. Below, we consider each component in turn.

In Ashmore et al.'s (2004) framework, self-categorization not only describes the cognitive placing of oneself into a social category, but also includes the extent to which individuals perceive themselves as prototypical of and similar to other members of their group. That is, individuals tend to stereotype themselves in terms of the ingroup stereotype, and do not just stereotype outgroup members. The self-categorization component also includes the degree of certainty with which individuals self-categorize as part of a given group.

The evaluative component, like Tajfel's (1981) definition, denotes the extent to which an individual evaluates a given social identity in positive or negative terms. That is, it captures an individual's positive or negative attitude toward that identity. In line with Luhtanen and Crocker (1992), evaluation can be subdivided into private regard (one's own evaluative ratings) and public regard (one's perception of others' 
evaluative ratings of one's identity). In contrast, importance is the degree to which an individual perceives a given social identity as important to their self-concept. Ashmore et al. (2004) contended that researchers typically refer to this dimension when using the term 'strength of identification'. Importance can be subdivided into explicit and implicit importance. Explicit importance is an individual's subjective sense of how important a given social identity is to their self-concept. Implicit importance assumes that an individual's identities are hierarchically structured according to their importance for the individual's sense of self (see, for example, Stryker, 2000). Individuals need not, however, be consciously aware of the implicit importance of their identities.

The fourth component, attachment and interdependence, refers to the sense of emotional involvement and oneness with a group. It defines the extent to which individuals perceive members of a given group to receive similar treatment in society (interdependence/mutual fate), the extent to which they are emotionally tied to the group (attachment/affective commitment), and the extent to which they see the self and the group as overlapping (interconnection of self and others). The fifth component, social embeddedness, describes the extent to which individuals' social identities are implicated in their everyday lives and social relationships. The sixth component, behavioural involvement, denotes the extent to which individuals' behaviour and actions are functionally dependent on their social identity. Content and meaning constitute the final component in Ashmore et al.'s (2004) framework. This component reflects both the extent to which a social group's (stereo-)typical characteristics are seen as reflecting the group members' traits (self-attributed characteristics), and the ideological beliefs surrounding the group's experience and role in society, as well as the internalised story of the group and one's membership thereof (narrative).

Ashmore et al. (2004) argued that although these components often covary, they need not converge or correlate for every given category and individual. For example, a person might evaluate a social category positively and consider it very important, while another person might evaluate that category positively without considering it important. Similarly, a person might consider two social categories important, but evaluate one positively and one negatively. While we acknowledge this complexity, we use the summary term 'social identification' in the remainder of this chapter-both for the sake of simplicity and to be consistent with earlier research and theories. We also note that although social identification is best understood as multidimensional, a single-item measure of social identification has been shown to be reliable, valid, and useful in research practice (Postmes, Haslam \& Jans, 2013). In the next section, we discuss social identity theory as a perspective on the consequences of social identification for intergroup relations. 


\section{Social Identity Theory}

\section{Intergroup bias and the "minimal group paradigm"}

Social identification changes the nature of social categorization. We divide others not just into groups, but into groups we are also part of (ingroups) and those we are not part of (outgroups). Social identities determine whom we categorize as "us" and "them". Dividing others into "us" and "them", in turn, changes how we treat members of these groups. Intergroup bias refers to "the systematic tendency to evaluate one's [ingroup] or its members more favourably than [an outgroup] or its members" (Hewstone, Rubin \& Willis, 2002, p. 576). Social categorization into ingroup and outgroup is, by definition, necessary for intergroup bias to occur. But is it also sufficient?

Tajfel, Flament, Billig and Bundy (1971) recognised that to answer this question, they needed to strip social categorization of the regular trappings of group membership. That is, they set out to study social categorization unconfounded by prior attitudes, historical ties, face-to-interactions, and-in contrast to earlier research (Sherif, Harvey, White, Hood \& Sherif, 1954/1961) - in the absence of direct competition or conflicting goals. To that end, Tajfel and colleagues developed the 'minimal group paradigm' for examining the effects of social categorization in laboratory settings. In the original studies, the researchers randomly allocated participants into one of two groups, ostensibly based on trivial criteria such as their responses in a visual-judgement task (Experiment 1) or their preference for paintings by one of the abstract artists Klee and Kandinsky (Experiment 2). Participants-in this case, adolescent boys-did not know which of their classmates were in which group.

Next, the researchers isolated participants into cubicles, and asked them to distribute money between two other participants according to a range of predefined choices. Participants made these choices with complete anonymity, knowing the group memberships but not the names of the other participants. Still, participants tended to favour members of their own group when allocating money between an ingroup and an outgroup member-choosing a fair allocation less often than when allocating money between two outgroup or two ingroup members. As the experimental setting ruled out alternative explanations for intergroup bias, Tajfel et al. (1971) concluded that social categorization was indeed sufficient to elicit discrimination. Since the original studies were published, researchers have used this paradigm to uncover bias across many other measures, including, for example, better recall of unfavourable outgroup over ingroup behaviours (Howard \& Rothbart, 1980).

Researchers have debated various processes that could explain why social categorization leads to discrimination in minimal group studies (see Hewstone et al., 2002, for a review). Tajfel (1970) first offered a norm-based explanation, before devel- 
oping the social-identity explanation (Tajfel \& Turner, 1979) that has since become seminal (but see Iacoviello \& Spears, 2018, for a recent reconsideration of the social norm explanation). In minimal group studies, participants show ingroup-serving preferences that resemble well-documented self-serving biases and behaviours. Tajfel and Turner (1979) argued that just as individuals strive for positive self-esteem, they also strive for positive social identity. Further, just as individuals derive positive self-esteem from favourable comparisons with others, they derive positive social identity from favourable comparisons between the ingroup and a relevant outgroup. Discriminating against an outgroup (for example, allocating rewards to an ingroup member) elevates the ingroup and, thereby, positively differentiates the ingroup from the outgroup. Indeed, the idea that positive differentiation enhances esteem through a positive identi-ty (known as the self-esteem hypothesis) has received extensive empirical support (Aberson, Healy \& Romero, 2000; Rubin \& Hewstone, 1998). Tajfel and Turner (1979) thus explained intergroup bias as a way to achieve positive social identity.

Others, however, have argued that social identification leads to discrimination, rather than discrimination being a way to achieve positive social identification (Hinkle \& Brown, 1990; Turner \& Reynolds, 2001). Experimental studies found that manipulating social identification can indeed increase bias (Branscombe \& Wann, 1994; Perreault \& Bourhis, 1999), though correlational studies tend to find only weak support for this relationship (Hinkle \& Brown, 1990; Mullen, Brown \& Smith, 1992). In any case, researchers have proposed other explanations for participants' behaviour in minimal group studies that do not rely on social identity as a mechanism. Most likely, participants' responses to minimal group categorizations are multiply determined (see Spears \& Otten, 2012, for a review).

Thus far, we have talked about intergroup bias without referencing the target of discrimination. Indeed, Tajfel and colleagues' (1971) studies could not differentiate between participants denigrating the outgroup and favouring the ingroupboth would manifest as discrimination. Marilynn Brewer $(1999,2007)$ argued that researchers need to distinguish between different consequences of social categorization, all of which could underlie intergroup bias. Thus far, we have considered the argument that people think about ingroup and outgroup in "me"-"not me" terms, and favour ingroup members ("us") over others ("not us"). Such ingroup favouritism is directed toward the ingroup, and not against any specific outgroup. Discrimination, in this case, does not stem from direct hostilities against outgroup members (Brewer, 1999). Instead, discrimination results from reserving favours and benefits for ingroup members. Some have argued that ingroup favouritism explains contemporary discrimination better than outgroup-directed hostilities (Greenwald \& Pettigrew, 2014).

In other cases, intergroup bias is directed against an outgroup and its members. Mummendey et al. (1992), however, found that participants did not differenti- 
ate between minimal ingroup and outgroup members when distributing negative outcomes (that is, punishments rather than rewards). This suggests that mere categorization into "us" and "not us" is not sufficient to elicit outgroup-directed discrimination. Sexual prejudice (Herek \& McLemore, 2013), for example, does not seem to be motivated by the desire to advantage one's ingroup. Instead, sexual prejudice is often motivated by the desire to distance oneself from the outgroup: "I'm not gay... I'm a real man!" (Falomir-Pichastor \& Mugny, 2009). Discrimination thus arises from individuals harming outgroup members in the effort to distance themselves ("me") from a stigmatised outgroup ("them").

As discussed above, ingroup favouritism does not usually necessitate outgroup derogation. The two are, however, intrinsically linked in some situations (Brewer, 1999, 2007). For example, people sometimes perceive an outgroup's interests as being at odds with their ingroup's-especially when they see the outgroup as a threat to the ingroup (Sherif et al., 1954/1961; Stephan \& Stephan, 2000). In intergroup conflict, people might harm the outgroup in order to benefit their ingroup. This relationship tends to be stronger for individuals who strongly identify with the threatened group than for those to whom the threatened group is less important (see, for example, Bizman \& Yinon, 2001; Tausch, Hewstone, Kenworthy, Cairns \& Christ, 2007). Discrimination thus results from protecting a valued ingroup ("us") against the perceived threat from an outgroup ("them").

\section{Social identity and intergroup relations}

Social identity theory has important implications for understanding intergroup processes beyond artificially created laboratory settings. Tajfel (1981) developed social identity theory to understand intergroup relations by explaining how individuals perceive, and act as a consequence of, their membership in social groups. The theory seeks to understand intergroup relations in real-life settings defined by hierarchies and status differences across groups. The theory contends that individuals have a need to achieve and maintain positive distinctiveness from other groups. This means that individuals strive to demonstrate that the ingroup is, in some form or other, better than the outgroup—or at least different from them (see, for example, Mummendey \& Schreiber, 1983). Outside of the laboratory, individuals often attach value and meaning to their self-categorizations. As such, social identities help explain how individuals relate to and perceive other social groups.

Social identity theory thus argues that when individuals identify with their ingroup and when functional relations between ingroup and outgroup are salient, individuals strive to maintain or attain positive distinctiveness. According to Brewer (2000), this need for positive distinctiveness may lead to intergroup accentuation (individuals minimise differences between ingroup members, and maximise differences between ingroup and outgroup members), ingroup favouritism (individuals 
generalise positive affect to ingroup members, but not outgroup members), and social competition (individuals devalue the outgroup when doing so elevates the ingroup). Together, these dynamics can help explain intergroup conflict and groupbased status relations in societies. In his theorising, Tajfel (1978) focused on what this means for members of lower-status groups. Below, we discuss how group status influences individuals' strategies for achieving positive distinctiveness.

\section{Group status and strategies for achieving positive distinctiveness}

In their quest for a positive social identity and positive distinctiveness, individuals are bound by, and take into consideration, group status and group boundaries. Intergroup attitudes and behaviour are a function of how low or high the ingroup and outgroup are in their relative status, how stable and legitimate intergroup relations are perceived to be, and whether group boundaries are permeable or impermeable (Ellemers, Wilke \& van Knippenberg, 1993; for a review, see Turner, 1999). These factors interact in shaping how members of low-status and high-status groups attain and/or maintain positive distinctiveness. When group boundaries are permeable, low-status group members may engage in social mobility strategies, at least if they do not identify strongly with their group. That is, they may leave or disassociate from the ingroup, and may attempt to join the higher-status outgroup. When group boundaries are impermeable, low-status group members may instead attempt to bolster their social identity by engaging in social creativity or social competition strategies.

Social creativity is a strategy employed by low-status groups when they perceive status relations as stable and legitimate, and when group boundaries are impermeable. This strategy involves changing elements of the comparative situation in favour of the ingroup. For example, low-status group members might seek to challenge negative evaluations of characteristics attributed to their group (as in the 'Black is Beautiful' movement in the 1970s). Alternatively, they might compare their ingroup to an outgroup that is less valued or of even lower status than the ingroup (so-called 'downward social comparison'). Social competition (or: collective action) is a strategy employed by low-status groups when they perceive status relations as unstable and illegitimate, and when group boundaries are impermeable. An example would be militant Black South Africans challenging the old Apartheid system in South Africa. In this case, low-status group members tend to perceive the outgroup in less positive terms, and identify more strongly with the ingroup.

Social psychological research has extensively tested these predictions of social identity theory. For example, both experimental (Brown \& Wade, 1987; Turner \& Brown, 1978) and meta-analytic (Mullen et al., 1992; Bettencourt, Charlton, Dorr \& Hume, 2001) studies demonstrated that group status can affect the nature of intergroup relations. In particular, researchers observed that members of high- 
status groups tend to show more ingroup bias than members of low-status groups, both in terms of more favourable ingroup and less favourable outgroup evaluations.

Some of the strategies described by social identity theory have systemjustifying consequences (Jost \& Banaji, 1994). That is, they can entrench the status quo and maintain an unjust system. For example, social mobility strategies mean that some group members advance in social status, and thus make the low-status group seem even lower in status. The success of the few can justify the lower status of the many as resulting from lower competence. For the remaining group members, the success of some group members (who become tokens of ingroup success) may reduce their desire to improve the situation for their group (Brown, 200o). Similar arguments can be made about social creativity strategies. Social identity theory thus recognizes two strategies, social mobility and social creativity, that can be a double-edged sword. While they help to protect self- and group-esteem, they also threaten the group's ability to collectively rise up the social ladder.

\section{Beyond social identity theory}

Social psychological theories and research have evolved since the inception of social identity theory. Researchers have put forward other theoretical explanations of what motivates social identification and shapes intergroup relations. We briefly review three such theories: optimal distinctiveness theory (Brewer, 1991), subjective uncertainty reduction theory (Hogg, 2007; Hogg \& Abrams, 1993), and terror management theory (Greenberg et al., 1990).

Optimal distinctiveness theory (Brewer, 1991; Brewer \& Pickett, 1999) posits that individuals are motivated by two opposing needs, a need for assimilation and a need for differentiation. On the one hand, individuals seek to belong to, and be immersed in, social groups-and strive to avoid the risks of isolation and stigmatization. On the other hand, assimilation risks deindividuation and loss of self-definition-in particular, when others are perceived as too similar to the self. Individuals thus seek to differentiate themselves from others. In this view, an optimal identity is one that satisfies someone's need for assimilation with the ingroup, as well as their need for distinctiveness between the ingroup and outgroups.

Identifying with more and less inclusive groups allows individuals to balance these opposing needs. Optimal distinctiveness theory (Brewer, 1991) proposes that individuals identify with social groups that are inclusive enough to satisfy their need for assimilation, but not too inclusive to conflict with their need for distinctiveness. To the extent that individuals differ in the strengths of these needs, they will also differ in the social categories they choose to identify with. This perspective argues for a dual-process model to explain ingroup favouritism and outgroup derogation: Individuals favour the ingroup to affirm their need for assimilation, but also derogate the outgroup to seek differentiation and distinctiveness from relevant outgroups 
(see Leonardelli \& Brewer, 2001).

Subjective uncertainty reduction theory (Hogg, 2000, 2007; Hogg \& Abrams, 1993) posits that individuals need to feel certain about their social world and to maintain control over their lives-and thus seek to reduce uncertainty in their social perceptions. Affiliating with social groups is one way to reduce uncertainty. Self-categorization and social identification with groups-in particular, if they provide clear social norms for self-definition, social perception and behaviourgive individuals certainty about their place in the social world (see Hogg, 2007, for a review). As a consequence, individuals may evaluate ingroup members more positively than outgroup members because only the former reduce their uncertainty about the social world (see Grieve \& Hogg, 1999). Subjective uncertainty reduction theory has particular relevance for situations in which individuals find themselves in new intergroup settings (for example, immigrants arriving in a country, or students arriving at their new university). Similarly, this theory helps explain why members of long-standing groups show ingroup bias when faced with system changes that could destabilize the status of their ingroup (Mullin \& Hogg, 1998).

Terror management theory (Greenberg et al., 1990; Pyszczynski, Greenberg \& Solomon, 1997) assumes that individuals have an inherent need for selfpreservation, and that this need is threatened when we are made aware of the inevitability of our death (so-called 'mortality salience'). Affiliating with social groups may overcome this mortality threat since such affiliation provides meaning and stability. More broadly, individuals may adopt the group's cultural worldview, and thus achieve a sense of symbolic immortality (see Castano, Yzerbyt, Paladino \& Sacchi, 2002, for a review). Religious beliefs, for example, can 'buffer' the adverse effects of mortality salience (see Newheiser et al., 2013). Terror management theory (Greenberg et al., 1990) also argues that individuals hold negative attitudes toward outgroups because they see them as a threat to their ingroup's worldview (for a review, see Solomon, Greenberg \& Pyszczynski, 1991).

\section{Multiple Categorization}

Thus far, we have discussed social identification in relation to a single social categorization. Social identity theory states that how we feel about and act toward others depends on whether we consider them as part of our ingroup. In some situations, the distinction between ingroup and outgroup members rests on a single dimension of categorization. On a football pitch, for example, players tend to think of their own team as "us", and of the other team as "them", and try their best to make their own team win. In many situations, however, this distinction rests on multiple social categories. Individuals differ in how they make sense of their multiple group memberships, and often combine and organize their social categories in 
complex and differentiated ways. In recent years, researchers have made significant advances in understanding such multiple categorization processes, as well as their consequences for intergroup relations (see Crisp \& Hewstone, 2007, for a detailed review). We devote the remainder of this chapter to multiple categorization and its relationship to intergroup attitudes. We review research on crossed categorization, common ingroup and dual identification processes, ingroup projection, social identity complexity, and social identity inclusiveness and structure.

\section{Crossed categorization}

Individuals belong to a range of social groups, some of which cross-cut each other. Imagine, for example, a group of male and female students, half of whom study psychology, while the other half studies chemistry. The categories 'student' and 'gender' are thus cross-cutting each other (if we assume that both male and female students are enrolled in both subjects). The crossed categorization approach assumes that individuals can process information about multiple cross-cutting categorizations, and are able to consider more than one categorization when deciding whether someone is an ingroup or outgroup member (Brown \& Turner, 1979; see Brewer, 2000). When two such categorizations are salient, individuals meet people with whom they share both category memberships (double ingroups), share either of the category memberships (mixed groups/partial ingroups), or share neither category membership (double outgroups).

Let us assume that, with reference to the previous example, a male psychology student is asked to make judgements about his fellow psychology and chemistry students. This individual would perceive other psychology students either as double ingroup members (if they are male) or as mixed ingroup/outgroup members (if they are female). He would perceive chemistry students either as mixed ingroup/outgroup members (if they are male) or as double outgroup members (if they are female). Deschamps and Doise (1978) studied how crossed categorization affects evaluations of others. Participants rated targets from each of four combinations of gender and two minimal groups (Experiment 2). In this and similar studies, participants tend to evaluate double ingroups more positively than mixed groups, whom participants evaluate more positively than double outgroups (Migdal, Hewstone \& Mullen, 1998; Urban \& Miller, 1998). This corresponds to an additive pattern of evaluation where more shared group memberships lead to more positive evaluations.

Researchers have, however, observed other patterns of evaluation (Crisp \& Hewstone, 2007). In some situations, a single category dimension dominates target evaluations. That is, all targets that share the dominant category membership are evaluated more positively than all targets that lack this category membership. In other situations, observers may evaluate all targets that share at least one category 
membership equally positively (social inclusion). Alternatively, observers may evaluate all targets that do not share both category memberships equally negatively (social exclusion). Other situations lead to patters of evaluation in which the effects of one category dimension depend on whether targets share another, more important category membership with the observer. For example, a target's gender could affect that target's evaluation only if that target shares the participant's nationality (hierarchical acceptance), or only if that target does not share the participant's nationality (hierarchical rejection). For example, a British man would distinguish between male and female targets only if judging a target who was British, but would not do so if the target were German. Finally, observers may evaluate all target groups as equally positive (equivalence). Crisp and Hewstone (1999) found that although the additive pattern was the most common result of crossed-categorization studies, all the other patterns occurred in particular social circumstances.

\section{Common ingroup identity model}

Above, we have discussed examples of orthogonal categorizations in which two categorizations vary independently. Social categories, however, are often hierarchical, that is, subordinate categories are nested in superordinate, overarching categories. The common ingroup identity model (Gaertner \& Dovidio, 2000; Gaertner, Dovidio, Anastasio, Bachman \& Rust, 1993) stipulates that individuals can think of themselves and others at different levels of inclusiveness. For example, the national categories 'British', 'Italian' and 'German' are subordinate to the more inclusive, superordinate category 'Europe.' The model assumes that individuals may categorize themselves and others either as part of subordinate ingroups and outgroups ('us' and 'them'), or as part of superordinate, common ingroups ('we'). As a consequence, the model proposes that encouraging individuals to use a superordinate, instead of subordinate, categorizations has positive consequences for intergroup perception. Such recategorization (e.g., from former outgroup member, 'German', to superordinate ingroup member, 'European') should then reduce intergroup bias.Research demonstrated that, as predicted, using common ingroup identities can improve attitudes to (former) outgroup members (Gaertner \& Dovidio, 2000).

\section{Dual identity model}

The dual identity model (Gaertner et al., 1993; Gaertner, Dovidio, Guerra, Hehman \& Saguy, 2016)) is an extension of the common ingroup identity model. This model recognises two ways of adopting a superordinate identity. Individuals who espouse a one-group identity adopt the superordinate identity and abandon the subordinate identity. Individuals who espouse a dual identity adopt the superordinate identity but also maintain the subordinate identity (e.g., 'I am proud to be both British and 
European'). Dual identities could overcome some problematic consequences of one-group identities, as reviewed below.

The common ingroup identity model has been criticized for its emphasis on recategorization, which risks depriving individuals of valued subgroup identities. This concern is particularly relevant for minority-group members who risk being subsumed in a superordinate category dominated by majority-group members (see Brewer \& Gaertner, 2004; Simon, Aufderheide \& Kampmeier, 2001). Recategorization may thus be an unrealistic means for improving intergroup relations outside the laboratory (Brewer \& Gaertner, 2004). Recategorization may further exacerbate hostile intergroup relations by threatening valued identities, especially in intergroup contact where groups differ in size, status, and power (Hewstone et al., 2002). Further, Dovidio, Saguy, Gaertner and Thomas (2012) recognised that focusing on common ingroups can distract from ongoing status hierarchies and thus entrench the status quo.

The dual identity model offers a way to reap the benefits of common ingroup identities, while protecting against its problematic consequences. The dual-identity model thus proposes an integrationist view of intergroup relations, while the common ingroup identity model has more in common with an assimilationist approach (Dovidio, Kawakami \& Gaertner, 2000; Dovidio, Gaertner \& Saguy, 2009). Experimental research (Ufkes, Calcagno, Glasford \& Dovidio, 2016) found that, as predicted, recategorization into a common ingroup identity reduced collective action intentions among disadvantaged-group members, while recategorization in a dual identity did not. Others have argued that, in some cases, dual identities lead to more positive outgroup attitudes than a superordinate identity alone. This should be the case when the superordinate category is too inclusive to provide individuals with adequate distinctiveness (Hornsey \& Hogg, 2000). Empirical studies have documented positive consequences for intergroup attitudes when both subgroup and superordinate groups are equally salient (for example, Gaertner, Dovidio \& Bachman, 1996).

\section{Ingroup projection model}

A problem with both of the preceding models is that individuals tend to expect similarities between themselves and others. That is, they engage in social projection (see Robbins \& Krueger, 2005, for a review). Ingroup projection refers to situations in which individuals perceive the defining (often positive) characteristics of the common ingroup as reflecting only those of the former subordinate ingroup (see Wenzel, Mummendey, Weber \& Waldzus, 2003). Ingroup projection may limit the extent to which a common ingroup identity exerts positive effects for intergroup relations. Consider, for example, two subgroups, 'English' and 'Scottish', nested within a superordinate category, 'British'. An English person should find it easy to identify as 
British if they perceive the category 'British' to reflect the characteristics associated with English people. In that case, the subordinate outgroup category 'Scottish' is not included in the common ingroup, at least not to the same extent. Identifying as 'British' would no longer be sufficient for encouraging positive attitudes towards the subordinate outgroup 'Scottish'.

In majority-minority group relations, ingroup projection may have particularly pernicious effects on intergroup relations when there is no obvious set of features describing the common identity. Drawing on self-categorization theory (Turner et al., 1987), Mummendey and Wenzel (1999) argued that the majority group's values and attributes are often treated as the default values and attributes of the common identity. What is thought of as an inclusive category might be seen by minority-group members as a projection of the majority group's values onto them. While ingroup projection might not be problematic for majority-group members, it can represent a symbolic threat (Stephan \& Stephan, 2000) to minority-group members. This threat may sow the seeds for intergroup discord (Brown, 2000). Mummendey and Wenzel (1999) propose that the optimal common identity is one that is amorphously defined so as to allow various interpretations of what category membership entails.

\section{Social identity complexity}

The multiple categorization approaches discussed above primarily pertain to the categorization of outgroup members in functional relation to the ingroup. For example, in the crossed-categorization approach, the extent to which an outgroup member of one category shares ingroup membership in another category is critical. In the common-ingroup and dual identity models, the extent to which the outgroup is included in a common ingroup is key. Below, we discuss 'social identity complexity' as an approach that is explicitly about individuals' self-categorization, with less reference to comparative outgroups.

The social identity complexity approach assumes that individuals have different ways of subjectively combining their numerous identities (see Schmid \& Hewstone, 2011, for a review). Social identity complexity refers to an individual's subjective representation of the interrelationships among their multiple identities, where complexity can range on a continuum from low to high (Roccas \& Brewer, 2002). Individuals often perceive their multiple social identities as largely overlapping. Such individuals regard only people with whom they share all group memberships as ingroup members, and regard all people with whom they share none or only a few group memberships as outgroup members. A person who views their ingroups in this manner espouses a simple identity structure and thus evinces low social identity complexity.

A person high in social identity complexity is aware that she belongs to 
multiple groups and recognizes that these multiple categories do not always overlap. For example, this person would understand that her academic colleagues (occupational ingroup) do not necessarily overlap with the local branch of her political party (political ingroup). Similarly, a White-British man has a more complex identity structure to the extent that he recognizes that not all British people are White, and accepts that others will share some ingroup memberships with him, but not others.

Researchers distinguish between overlap and similarity complexity (Brewer \& Pierce, 2005). Overlap complexity refers to the perceived numerical overlap between multiple categories, while similarity complexity refers to the extent to which an individual perceives these multiple categories to be interrelated in terms of their prototypical connotations and attributes. For example, a person low in overlap complexity perceives all members of one ingroup (e.g., 'Christians') to simultaneously share membership of another ingroup (e.g., 'British'). A person low in similarity complexity perceives one ingroup to be very similar to their other ingroups (e.g., considering the typical Christian and the typical British person to be very similar).

Several studies have documented a positive relationship between social identity complexity and intergroup attitudes. In the US, Brewer and Pierce (2005), for example, found social identity complexity to be associated with more tolerance, reduced intergroup bias and greater support for affirmative action and multiculturalism. In Northern Ireland, Schmid, Hewstone, Tausch, Cairns and Hughes (2009) found social identity complexity to be associated with more tolerance and less ingroup bias. In Germany and England, Schmid, Hewstone and Al Ramiah (2013) found social identity to be associated with less ingroup bias and less social distance. Together, these studies showed that fostering more complex conceptions of multiple social identities could improve intergroup relations.

\section{Social identity inclusiveness and structure}

Social identity complexity, as reviewed above, measures to what extent a person is aware that their various ingroups do not always overlap and are not always similar. Past research (Brewer \& Pierce, 2005; Schmid et al., 2009, 2013), however, did not measure whether that person also identifies with the various partial ingroups resulting from their multiple group memberships. For example, a Turkish-Belgian Muslim is aware that there are many Belgians of different ethnic backgrounds, but might not consider all these other Belgians as ingroup members. Recent studies (van Dommelen, Schmid, Hewstone, Gonsalkorale \& Brewer, 2015; Reimer, Kamble, Schmid \& Hewstone, 2020) extended research on social identity complexity by considering how individuals combine multiple group memberships to construct their subjective ingroup.

Van Dommelen and colleagues (2015) studied social identification among Turkish-Belgian and Turkish-Australian Muslims with a novel experimental paradigm. 
Intersection

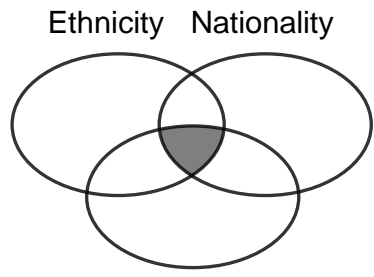

Religion
Dominance

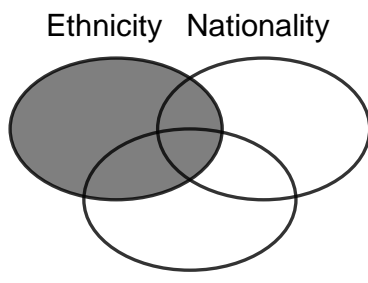

Religion
Merger
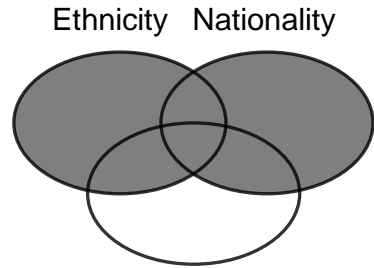

Religion

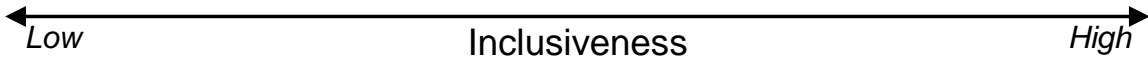

Figure 1. Schematic representations of social identity structures, ordered by social identity inclusiveness (van Dommelen et al., 2015). Shaded regions represent the groups which a participant has to categorize as "us" to be assigned that structure.

Participants viewed identity cards, each representing a person with whom they shared none, one, two, or all of three group memberships. Participants judged cards as "us" and "not us", showing whom they included in, and excluded from, their ingroup. Participants' responses reflected various social identity structures that varied in social identity inclusiveness. Figure 1 shows examples of possible social identity structures. A Turkish-Belgian Muslim, for example, may consider only people who share their ethnicity, nationality, and religion as ingroup members (intersection). Someone else may consider all Turks, whatever their nationality or religion, as ingroup members (dominance). Another person may consider anyone who shares their ethnicity or nationality as ingroup members (merger). A person who includes more categories in their ingroup displays a more inclusive identity construal than someone who includes fewer categories in their ingroup.

Social identity theory argues that we favour ingroup members over outgroup members in our thoughts, feeling, and actions. Considering more people as "us" should extend ingroup favouritism to former (partial) outgroup members, and should thus reduce prejudice and discrimination (see Gaertner et al., 2016). In line with this prediction, van Dommelen et al. (2015) found more inclusive identities to correlate with more favourable attitudes. Similarly, Reimer et al. (2020) found that South Indians reported more warmth and less social distance for people they had categorized as "us" rather than "not us". Together, these studies showed that considering social identity inclusiveness and structure helps us to understand how people construct complex social identities from multiple, cross-cutting group memberships.

There are, of course, other ways in which social identification can be complex. 
Recent research (see, for example, Gaither, 2015; Reddy, 2018) has recognised that people can belong to more than one category in the same category domain (e.g., multi-racial people), that people can hold identities that are not recognised by others, and that people can change how they think about their identities over their lifetime. The social identity literature continues to evolve to address such complexities.

\section{Conclusion}

Since their inception, self-categorization theory and social identity theory have been at the heart of social psychological theorizing. They have emphasized-in isolation and in combination-the central role that social identity processes play in a range of social phenomena and, in particular, in intergroup relations. This chapter has provided a comprehensive overview of the so-called social identity perspective, encompassing both theories, and other approaches to social identity related to these theories (for example, optimal distinctiveness theory and subjective uncertainty reduction theory). In so doing, we have paid particular attention to defining self-categorization and social identification, the two concepts on which the social identity perspective rests. We have highlighted that social identification is a multidimensional phenomenon-a complexity that is often overlooked in social psychological research. Researchers interested in social identity phenomena must take this multidimensionality into account, not only in their own research, but also when making comparisons to and drawing conclusions from other research.

This chapter has focused on the role of social identity issues in intergroup relations. We have argued that, although social identity theory has significantly advanced our understanding of intergroup relations, self-categorization and social identification are not sufficient to explain negative intergroup attitudes and behaviour. Any examination of intergroup relations needs to account for the broader social, historical, political or ideological context, and for the interplay between prevailing socio-structural conditions (see Tajfel, 1981). We have also drawn attention to an evolving body of research that considers how multiple categorization processes relate to intergroup relations. Although much of social psychological research seeks to understand intergroup phenomena, the underlying motivation of many social psychologists is to find ways of eradicating prejudice, reducing conflict, or improving intergroup relations. Multiple categorization approaches hold particular promise in that respect. Increasing awareness of the multiplicity of social identities often translates into more differentiated perceptions of multiple ingroups, which tend to covary with more positive intergroup attitudes.

In sum, this chapter has provided an overview of the theoretical foundations and key research studies that underpin the social identity perspective in social psychology. By providing a more differentiated account of the social identity 
perspective-that is, by considering conceptual definitions, associated processes, and the multiplicity of identities - we hope to have offered useful insights, both to new and established scholars in the field of social identity research. 


\section{References}

Aberson, C., Healy, M. \& Romero, V. (200o). Ingroup bias and self-esteem: A meta-analysis. Personality and Social Psychology Review, 4, 157-173.

Abrams, D. \& Hogg, M. A. (2010). Social identity and self-categorization. In J. F. Dovidio, M. Hewstone, P. Glick \& V. M. Esses (Eds.), The SAGE handbook of prejudice, stereotyping and discrimination (pp. 179-193). London, UK: SAGE Publications.

Ashmore, R. D., Deaux, K. \& McLaughlin-Volpe, T. (2004). An organizing framework for collective identity: Articulation and significance of multidimensionality. Psychological Bulletin, 130, 80-114.

Baumeister, R. F. \& Leary, M. R. (1995). The need to belong: Desire for interpersonal attachments as a fundamental human motivation. Psychological Bulletin, 117, 497-529.

Bettencourt, B. A., Charlton, K., Dorr, N. \& Hume, D. L. (2001). Status differences and ingroup bias: A meta-analytic examination of the effects of status stability, status legitimacy, and group permeability. Psychological Bulletin, 127, 520542.

Bizman, A. \& Yinon, Y. (2001). Perceived threat and Israeli Jews' evaluations of Russian immigrants: The moderating role of Jewish and Israeli identity. International Journal of Intercultural Relations, 25, 691-704.

Branscombe, N. R. \& Wann, D. L. (1994). Collective self-esteem consequences of outgroup derogation when a valued social identity is on trial. European Journal of Social Psychology, 24, 641-657.

Brewer, M. B. (1991). The social self: On being the same and different at the same time. Journal of Personality and Social Psychology, 17, 475-482.

Brewer, M. B. (1999). The psychology of prejudice: Ingroup love or outgroup hate? Journal of Social Issues, 55, 429-444.

Brewer, M. B. (2000). Reducing prejudice through cross-categorization: Effects of multiple social identities. In S. Oskamp (Ed.), Reducing prejudice and discrimination (pp. 165-183). Hillsdale, NJ: Erlbaum.

Brewer, M. B. (2007). The social psychology of intergroup relations: Social categorization, ingroup bias, and outgroup prejudice. In A. W. Kruglanski \& E. T. Higgins (Eds.), Social psychology: Handbook of basic principles (2nd ed., pp. 695-715). New York, NY: Guilford Press.

Brewer, M. B. \& Gaertner, S. L. (2004). Toward reduction of prejudice: Intergroup contact and social categorization. In R. Brown \& S. L. Gaertner (Eds.), Blackwell handbook of social psychology: Intergroup processes (pp. 451-474). Oxford, UK: Blackwell.

Brewer, M. B. \& Pickett, C. L. (1999). Distinctiveness motives as a source of the social self. In T. R. Tyler, R. M. Kramer \& O. P. John (Eds.), The psychology 
of the social self (pp. 71-87). Mahwah, NJ: Erlbaum.

Brewer, M. B. \& Pierce, K. P. (2005). Social identity complexity and outgroup tolerance. Personality and Social Psychology Bulletin, 31, 428-437.

Brown, R. (2000). Social identity theory: Past achievements, current problems and future challenges. European Journal of Social Psychology, 30, 745-778.

Brown, R. \& Turner, J. C. (1979). The criss-cross categorization effect in intergroup discrimination. British Journal of Clinical and Social Psychology, 18, 371-383.

Brown, R. \& Wade, G. (1987). Superordinate goals and intergroup behavior: The effect of role ambiguity and status on ingroup attitudes and task performance. European Journal of Social Psychology, 17, 131-142.

Cameron, J. E. (2004). A three-factor model of social identity. Self and Identity, 3, 239-262.

Campbell, D. T. (1958). Common fate, similarity, and other indices of the status of aggregates of persons as social entities. Systems Research and Behavioral Science, 3, 14-25.

Campbell, D. T. (1965). Ethnocentric and other altruistic motives. In D. Levine (Ed.), Nebraska symposium on motivation (Vol. 13, pp. 283-311). Lincoln, NE: University of Nebraska Press.

Castano, E., Yzerbyt, V., Paladino, M. P. \& Sacchi, S. (2002). I belong, therefore, i exist: Ingroup identification, ingroup entitativity, and ingroup bias. Personality and Social Psychology Bulletin, 28, 135-143.

Crisp, R. J. \& Hewstone, M. (1999). Differential evaluation of crossed category groups: Patterns, processes, and reducing intergroup bias. Group Processes and Intergroup Relations, 2, 303-333.

Crisp, R. J. \& Hewstone, M. (2007). Multiple social categorization. Advances in Experimental Social Psychology, 39, 163-254.

Deaux, K. (1996). Social identity. In A. W. Kruglanski \& E. T. Higgins (Eds.), Social psychology: Handbook of basic principles (pp. 777-798). New York, NY: Guilford Press.

Deschamps, J. C. \& Doise, W. (1978). Crossed category memberships in intergroup relations. In H. Tajfel (Ed.), Differentiation between social groups: Studies in the social psychology of intergroup relations (p. 141-158). London, UK: Academic Press.

Dovidio, J. F., Gaertner, S. L. \& Saguy, T. (2009). Commonality and the complexity of "we": Social attitudes and social change. Personality and Social Psychology Review, 13, 3-20.

Dovidio, J. F., Kawakami, K. \& Gaertner, S. L. (2000). Reducing contemporary prejudice: Combating explicit and implicit bias at the individual and intergroup level. In S. Oskamp (Ed.), Reducing prejudice and discrimination (pp. 137-163). Mahwah, NJ: Erlbaum.

Dovidio, J. F., Saguy, T., Gaertner, S. L. \& Thomas, E. L. (2012). From attitudes 
to (in)action: The darker side of "we". In J. Dixon \& M. Levine (Eds.), Beyond prejudice: Extending the social psychology of conflict, inequality and social change (pp. 248-268). Cambridge, UK: Cambridge University Press.

Ellemers, N., Kortekaas, P. \& Ouwerkerk, J. W. (1999). Self-categorization, commitment to the group and group self-esteem as related but distinct aspects of social identity. European Journal of Social Psychology, 29, 371-389.

Ellemers, N., Wilke, H. \& van Knippenberg, A. (1993). Effects of the legitimacy of low group or individual status on individual and collective status-enhancement strategies. Journal of Personality and Social Psychology, 64, 766-778.

Falomir-Pichastor, J. M. \& Mugny, G. (2009). "I'm not gay... I'm a real man!”: Heterosexual men's gender self-esteem and sexual prejudice. Personality and Social Psychology Bulletin, 35, 1233-1243.

Gaertner, S. L. \& Dovidio, J. F. (2000). Reducing intergroup bias: The common ingroup identity model. Hove, UK: Psychology Press.

Gaertner, S. L., Dovidio, J. F., Anastasio, P. A., Bachman, B. A. \& Rust, M. C. (1993). The common ingroup identity model: Recategorization and the reduction of intergroup bias. European Review of Social Psychology, 4, 1-26.

Gaertner, S. L., Dovidio, J. F. \& Bachman, B. A. (1996). Revisiting the contact hypothesis: The induction of a common ingroup identity. International Journal of Intercultural Relations, 20, 271-290.

Gaertner, S. L., Dovidio, J. F., Guerra, R., Hehman, E. \& Saguy, T. (2016). A common ingroup identity: Categorization, identity, and intergroup relations. In T. N. Nelson (Ed.), Handbook of prejudice, stereotyping, and discrimination (2nd ed., pp. 433-454). Hove, UK: Psychology Press.

Gaither, S. E. (2015). "mixed” results: Multiracial research and identity explorations. Current Directions in Psychological Science, 24, 114-119.

Greenberg, J., Pyszczynski, T., Solomon, S., Rosenblatt, A., Veeder, M., Kirkland, S. \& Lyon, D. (1990). Evidence for terror management II: The effects of mortality salience on reactions to those who threaten or bolster the cultural worldview. Journal of Personality and Social Psychology, 58, 308-318.

Greenwald, A. G. \& Pettigrew, T. F. (2014). With malice toward none and charity for some: Ingroup favoritism enables discrimination. American Psychologist, $69,669-684$.

Grieve, P. G. \& Hogg, M. A. (1999). Subjective uncertainty and intergroup discrimination in the minimal group situation. Personality and Social Psychology Bulletin, 25, 926-940.

Haslam, C., Jetten, J., Cruwys, T., Dingle, G. \& Haslam, S. A. (2018). The new psychology of health: Unlocking the social cure. London, UK: Routledge.

Haslam, S. A., Oakes, P. J., Reynolds, K. J. \& Turner, J. C. (1999). Social identity salience and the emergence of stereotype consensus. Personality and Social Psychology Bulletin, 7, 809-818. 
Haslam, S. A., Turner, J. C., Oakes, P. J., McGarty, C. \& Reynolds, K. J. (1998). The group as a basis for emergent stereotype consensus. European Review of Social Psychology, 8, 203-239.

Herek, G. M. \& McLemore, K. A. (2013). Sexual prejudice. Annual Review of Psychology, 64, 309-333.

Hewstone, M., Rubin, M. \& Willis, H. (2002). Intergroup bias. Annual Review of Psychology, 53, 575-604.

Hinkle, S. \& Brown, R. (1990). Intergroup comparisons and social identity: Some links and lacunae. In D. Abrams \& M. A. Hogg (Eds.), Social identity theory: Constructive and critical advances (pp. 48-70). New York, NY: Harvester Wheatsheaf.

Hogg, M. A. (2000). Subjective uncertainty reduction through self-categorization: A motivational theory of social identity processes and group phenomena. European Review of Social Psychology, 11, 223-55.

Hogg, M. A. (2007). Uncertainty-identity theory. In M. Zanna (Ed.), Advances in experimental social psychology (Vol. 39, pp. 70-126). San Diego, CA: Elsevier.

Hogg, M. A. \& Abrams, D. (1993). Towards a single-process uncertainty-reduction model of social motivation in groups. In M. A. Hogg \& D. Abrams (Eds.), Group motivation: Social psychological perspectives (pp. 173-190). New York, NY: Harvester Wheatsheaf.

Hornsey, M. J. \& Hogg, M. A. (2000). Assimilation and diversity: An integrative model of subgroup relations. Personality and Social Psychology Review, 4, $143-156$.

Howard, J. W. \& Rothbart, M. (1980). Social categorization and memory for ingroup and outgroup behavior. Journal of Personality and Social Psychology, $38,301-310$.

Iacoviello, V. \& Spears, R. (2018). “i know you expect me to favor my ingroup': Re-viving Tajfel's original hypothesis on the generic norm explanation of ingroup favouritism. Journal of Experimental Social Psychology, 76, 88-99.

Jackson, J. W. (1993). Realistic group conflict theory: A review and evaluation of the theoretical and empirical literature. Psychological Record, 43, 395-414.

Jackson, J. W. (2002). Intergroup attitudes as a function of different dimensions of group identification and perceived intergroup conflict. Self and Identity, 1, 11-33.

Jackson, J. W. \& Smith, E. (1999). Conceptualizing social identity: A new framework and evidence for the impact of different dimensions. Personality and Social Psychology Bulletin, 25, 120-135.

Jost, J. T. \& Banaji, M. R. (1994). The role of stereotyping in system-justification and the production of false consciousness. British Journal of Social Psychology, 33, $1-27$.

Leach, C. W., van Zomeren, M., Zebel, S., Vliek, M. L., Pennekamp, S. F., Doosje, 
B., ... Spears, R. (2008). Group-level self-definition and self-investment: A hierarchical (multicomponent) model of in-group identification. Journal of Personality and Social Psychology, 95, 144-165.

Leonardelli, G. J. \& Brewer, M. B. (2001). Minority and majority discrimination: When and why. Journal of Experimental Social Psychology, 37, 468-485.

Luhtanen, R. \& Crocker, J. (1992). A collective self-esteem scale: Self-evaluation of one's social identity. Personality and Social Psychology Bulletin, 18, 302-318.

Macrae, C. N. \& Bodenhausen, G. V. (2000). Social cognition: Thinking categorically about others. Annual Review of Psychology, 51, 93-120.

Martin, D. \& Macrae, C. N. (2007). A face with a cue: Exploring the inevitability of person categorization. European Journal of Social Psychology, 37, 806-816.

Migdal, M. J., Hewstone, M. \& Mullen, B. (1998). The effects of crossed categorization on intergroup evaluations: A meta-analysis. British Journal of Social Psychology, 37, 303-324.

Mullen, B., Brown, R. \& Smith, C. (1992). Ingroup bias as a function of salience, relevance, and status: An integration. European Journal of Social Psychology, $22,103-122$.

Mullin, B. A. \& Hogg, M. A. (1998). Dimensions of subjective uncertainty in social identification and minimal intergroup discrimination. British Journal of Social Psychology, 37, 345-365.

Mummendey, A. \& Schreiber, H. (1983). Better or different? Positive social identity by discrimination against, or differentiation from outgroups. European Journal of Social Psychology, 13, 389-397.

Mummendey, A., Simon, B., Dietze, C., Grünert, M., Haeger, G., Kessler, S., ... Schäferhoff, S. (1992). Categorization is not enough: Intergroup discrimination in negative outcome allocation. Journal of Experimental Social Psycho$\log y, 28,125-144$.

Mummendey, A. \& Wenzel, M. (1999). Social discrimination and tolerance in intergroup relations: reactions to intergroup difference. Personality and Social Psychology Review, 3, 158-174.

Newheiser, A., Hewstone, M., Voci, A., Schmid, K., Zick, A. \& Küpper, B. (2013). Social-psychological aspects of religion and prejudice: Evidence from survey and experimental research. In S. Clarke, R. Powell \& S. J (Eds.), Religion, intolerance, and conflict: A scientific and conceptual investigation (pp. 107125). Oxford, UK: Oxford University Press.

Oakes, P. J. (1987). The salience of social categories. In J. C. Turner, M. A. Hogg, P. J. Oakes, S. D. Reicher \& M. S. Wetherell (Eds.), Rediscovering the social group: A self-categorization theory (pp. 117-141). Oxford, UK: Blackwell.

Oakes, P. J., Turner, J. C. \& Haslam, S. A. (1991). Perceiving people as group members: The role of fit in the salience of social categorizations. British Journal of Social Psychology, 30, 125-144. 
Perreault, S. \& Bourhis, R. Y. (1999). Ethnocentrism, social identification and discrimination. Personality and Social Psychology Bulletin, 25, 92-103.

Phinney, J. (1990). Ethnic identity in adolescents and adults: Review of research. Psychological Bulletin, 108, 499-514.

Postmes, T., Haslam, S. A. \& Jans, L. (2013). A single-item measure of social identification: Reliability, validity, and utility. British Journal of Social Psychology, 52, 597-617.

Pyszczynski, T., Greenberg, J. \& Solomon, S. (1997). Why do we need what we need? A terror management perspective on the roots of human social motivation. Psychological Inquiry, 8, 1-20.

Reddy, G. (2018). Fluidity amidst structure: Multi-racial identity constructions across the life course of Malaysians and Singaporeans. Social Identities, 1-18.

Reimer, N. K., Kamble, S. V., Schmid, K. \& Hewstone, M. (2020). Intergroup contact fosters more inclusive social identities [Manuscript submitted for publication]. https://doi.org/10.31234/osf.io/zcgwt.

Richeson, J. A. \& Trawalter, S. (2005). On the categorization of admired and disliked exemplars of admired and disliked racial groups. Journal of Personality and Social Psychology, 89, 517-530.

Robbins, J. M. \& Krueger, J. I. (2005). Social projection to ingroups and outgroups: A review and meta-analysis. Personality and Social Psychology Review, 9, $32-47$.

Roccas, S. \& Brewer, M. B. (2002). Social identity complexity. Personality and Social Psychology Review, 6, 88-106.

Rubin, J. M. \& Hewstone, M. (1998). Social identity theory's self-esteem hypothesis: A review and some suggestions for clarification. Personality and Social Psychology Review, 2, 40-62.

Schmid, K. \& Hewstone, M. (2011). Social identity complexity: Theoretical implications for the social psychology of intergroup relations. In R. M. Kramer, G. J. Leonardelli \& R. W. Livingston (Eds.), Social cognition, social identity, and intergroup relations: A festschrift in honor of Marilynn B. Brewer (p. 77102). Hove, UK: Psychology Press.

Schmid, K., Hewstone, M. \& Al Ramiah, A. (2013). Neighborhood diversity and social identity complexity: Implications for intergroup relations. Social Psychological and Personality Science, 4, 135-142.

Schmid, K., Hewstone, M., Tausch, N., Cairns, E. \& Hughes, J. (2009). Antecedents and consequences of social identity complexity: Intergroup contact, distinctiveness threat, and outgroup attitudes. Personality and Social Psychology Bulletin, 35, 1085-1098.

Sellers, R. M., Rowley, S. A. J., Chavous, T. M., Shelton, J. N. \& Smith, M. A. (1997). Multidimensional inventory of black identity: A preliminary investigation of reliability and construct validity. Journal of Personality and Social Psychology, 
$73,805-815$.

Sherif, M. (1966). Group conflict and cooperation: Their social psychology. London, UK: Routledge.

Sherif, M., Harvey, O. J., White, B. J., Hood, W. R. \& Sherif, C. W. (1961). Intergroup conflict and cooperation: The Robbers Cave experiment. Retrieved from http://psychclassics.yorku.ca/Sherif/ (Original work published 1954)

Simon, B., Aufderheide, B. \& Kampmeier, C. (2001). The social psychology of minority-majority relations. In R. Brown \& S. L. Gaertner (Eds.), Blackwell handbook of social psychology: Intergroup processes (pp. 303-323). Oxford, UK: Blackwell.

Simon, B. \& Klandermans, B. (2001). Politicized collective identity: A social psychological analysis. American Psychologist, 56, 319-331.

Smith, E. R. \& Henry, S. (1996). An in-group becomes part of the self: Response time evidence. Personality and Social Psychology Bulletin, 22, 635-642.

Solomon, S., Greenberg, J. \& Pyszczynski, T. (1991). A terror management theory of social behavior: The psychological functions of self-esteem and cultural worldviews. In M. P. Zanna (Ed.), Advances in experimental social psychology (Vol. 24, pp. 93-159). San Diego, CA: Academic Press.

Son Hing, L. S. \& Zanna, M. P. (2010). Individual differences. In J. F. Dovidio, M. Hewstone, P. Glick \& V. M. Esses (Eds.), The SAGE handbook of prejudice, stereotyping and discrimination (pp. 163-178). London, UK: SAGE Publications.

Spears, R. \& Otten, S. (2012). Discrimination: Revisiting Tajfel's minimal group studies. In J. R. Smith \& S. A. Haslam (Eds.), Social psychology: Revisiting the classic studies (pp. 160-177). London, UK: SAGE Publications.

Steele, C. M., Spencer, S. J. \& Aronson, J. (2002). Contending with group image: The psychology of stereotype and social identity threat. In M. P. Zanna (Ed.), Advances in experimental social psychology (Vol. 34, pp. 379-440). San Diego, CA: Academic Press.

Stephan, W. G. \& Stephan, C. W. (200o). An integrated threat theory of prejudice. In S. Oskamp (Ed.), Reducing prejudice and discrimination (pp. 23-45). Mahwah, NJ: Lawrence Erlbaum Associates.

Stryker, S. (2000). Identity theory. In E. F. Borgatta \& R. J. V. Montgomery (Eds.), Encyclopedia of sociology (2nd ed., Vol. 2, pp. 1253-1258). Macmillan References.

Tajfel, H. (1969). Cognitive aspects of prejudice. Journal of Biosocial Science, 1, 173-191.

Tajfel, H. (1970). Experiments in intergroup discrimination. Scientific American, 223, 96-103.

Tajfel, H. (1978). Interindividual behaviour and intergroup behaviour. In H. Tajfel 
(Ed.), Differentiation between social groups: Studies in the social psychology of intergroup relations (pp. 27-6o). London, UK: Academic Press.

Tajfel, H. (1981). Human groups and social categories: Studies in social psychology. Cambridge, UK: Cambridge University Press.

Tajfel, H., Flament, C., Billig, M. G. \& Bundy, R. P. (1971). Social categorization and intergroup behaviour. European Journal of Social Psychology, 1, 149-178.

Tajfel, H. \& Turner, J. C. (1979). An integrative theory of intergroup conflict. In W. G. Austin \& S. Worchel (Eds.), The psychology of intergroup relations (pp. 33-48). Monterey, CA: Brooks/Cole.

Tajfel, H. \& Turner, J. C. (1986). The social identity theory of intergroup behaviour. In S. Worchel \& W. Austin (Eds.), Psychology of intergroup relations (pp. 7-24). Chicago, IL: Nelson Hall.

Tausch, N., Hewstone, M., Kenworthy, J., Cairns, E. \& Christ, O. (2007). Crosscommunity contact, perceived status differences and intergroup attitudes in Northern Ireland: The mediating roles of individual-level vs. group level threats and the moderating role of social identification. Political Psychology, $28,53-68$.

Turner, J. C. (1982). Towards a cognitive redefinition of the social group. In H. Tajfel (Ed.), Social identity and intergroup relations (pp. 15-40). Cambridge, UK: Cambridge University Press.

Turner, J. C. (1999). Some current issues in research on social identity and selfcategorization theories. In N. Ellemers, R. Spears \& B. Doosje (Eds.), Social identity: Context, commitment, content (pp. 6-34). Oxford, UK: Blackwell.

Turner, J. C. \& Brown, R. (1978). Social status, cognitive alternatives, and intergroup relations. In H. Tajfel (Ed.), Differentiation between social groups: Studies in the social psychology of intergroup relations (pp. 202-234). New York, NY: Academic Press.

Turner, J. C., Hogg, M. A., Oakes, P. J., Reicher, S. D. \& Wetherell, M. S. (1987). Rediscovering the social group: A self-categorization theory. Oxford, UK: Blackwell.

Turner, J. C., Oakes, P. J., Haslam, S. A. \& McGarty, C. A. (1994). Self and collective: Cognition and social context. Personality and Social Psychology Bulletin, 20, 454-463.

Turner, J. C. \& Reynolds, K. J. (2001). The social identity perspective in intergroup relations: Theories, themes and controversies. In R. Brown \& S. Gaertner (Eds.), Blackwell handbook of social psychology: Intergroup processes (pp. 133152). Malden, MA: Blackwell.

Ufkes, E. G., Calcagno, J., Glasford, D. E. \& Dovidio, J. F. (2016). Understanding how common ingroup identity undermines collective action among disadvantagedgroup members. Journal of Experimental Social Psychology, 63, 26-35.

Urban, L. M. \& Miller, N. M. (1998). A theoretical analysis of crossed categorization effects: A meta-analysis. Journal of Personality and Social Psychology, 74, 
894-908.

van Dommelen, A., Schmid, K., Hewstone, M., Gonsalkorale, K. \& Brewer, M. (2015). Construing multiple ingroups: Assessing social identity inclusiveness and structure in ethnic and religious minority group members. European Journal of Social Psychology, 45, 386-399.

van Zomeren, M., Postmes, T. \& Spears, R. (2008). Toward an integrative social identity model of collective action: A quantitative research synthesis of three socio-psychological perspectives. Psychological Bulletin, 134, 504-535.

Veenstra, K. \& Haslam, S. A. (2000). Willingness to participate in industrial protest: Exploring social identification in context. British Journal of Social Psychology, $39,153-172$.

Waddell, N. \& Cairns, E. (1986). Situational perspectives on social identity in Northern Ireland. British Journal of Social Psychology, 25, 25-31.

Wenzel, M., Mummendey, A., Weber, U. \& Waldzus, S. (2003). The ingroup as pars pro toto: Projection from the ingroup onto the inclusive category as a precursor to social discrimination. Personality and Social Psychology Bulletin, 29, 461-473. 